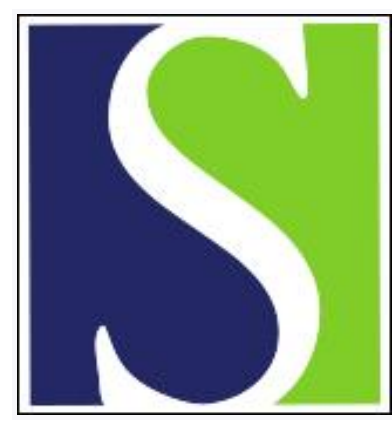

Scand J Work Environ Health 1997;23(3):214-220

https://doi.org/10.5271/sjweh.201

Issue date: Jun 1997

Specific antibodies against methyltetrahydrophthalic anhydride and risk factors for sensitization in occupationally exposed subjects

by Yokota K, Johyama Y, Yamaguchi K, Fujiki Y, Takeshita T, Morimoto $\mathrm{K}$

The following articles refer to this text: 2001;27(2):133-139;

2003;29(4):297-303

Key terms: pharmacia CAP system; rhinitis; smoking habit; specific immunoglobulin E; specific immunoglobulin G4; total immunoglobulin E

This article in PubMed: www.ncbi.nlm.nih.gov/pubmed/9243732 


\title{
Specific antibodies against methyltetrahydrophthalic anhydride and risk factors for sensitization in occupationally exposed subjects
}

\author{
by Kozo Yokota, ${ }^{1}$ Yasushi Johyama, ${ }^{1}$ Kyohei Yamaguchi, MD, ${ }^{1}$ Yukio Fujiki, MD, ${ }^{1}$ \\ Tatsuya Takeshita, MD, ${ }^{2}$ Kanehisa Morimoto, DMSc ${ }^{2}$
}

\begin{abstract}
Yokota K, Johyama Y, Yamaguchi K, Fujiki Y, Takeshita T, Morimoto K. Specific antibodies against methyltetrahydrophthalic anhydride and risk factors for sensitization in occupationally exposed subjects. Scand J Work Environ Health 1997;23(3):214-20.
\end{abstract}

Objectives Occupational exposure to methyltetrahydrophthalic anhydride (MTHPA) from an epoxy resin was studied to evaluate the nature of reported ocular and nasal complaints and some risk factors for sensitization.

Methods Seventy-three current and 22 former workers underwent a questionnaire survey and serologic investigations. Total and MTHPA-specific immunoglobulin ( $\mathrm{Ig}) \mathrm{E}$ levels were measured by means of a Pharmacia CAP system, and MTHPA-specific IgG4 levels were measured by enzyme immunoassay.

Results Forty-six (63\%) of the currently exposed workers had positive MTHPA-specific IgE, and no significant difference was found between those continuously or intermittently exposed (58\% and $71 \%$, respectively). Work-related ocular or nasal symptoms were significantly associated with specific IgE but not with specific IgG4. This finding indicates that there is an IgE-mediated mechanism in most cases of work-related symptoms associated with MTHPA exposure. The total IgE levels were significantly $(\mathrm{P}<0.005)$ higher in the specific IgE-positive workers than in the specific IgE-negative workers (geometric mean $101 \mathrm{IU} / \mathrm{ml}$ and $44.8 \mathrm{IU} / \mathrm{ml}$, respectively). Multiple logistic regression analysis also revealed that the group with high total IgE levels $(\geq 80 \mathrm{IU} / \mathrm{ml}$ ) had a significant relative risk (RR 4.7) of producing MTHPA-specific IgE as compared with the group with low total IgE levels $(<80 \mathrm{IU} / \mathrm{ml})$.

Conclusions These results show that MTHPA has a high sensitizing ability and that a high total IgE level is the most significant risk factor for workers exposed to MTHPA. However, to evaluate conclusively the effect of high total IgE levels on sensitization, further prospective studies are necessary.

Key terms Pharmacia CAP system, rhinitis, smoking habits, specific immunoglobulin E, specific immunoglobulin $\mathrm{G} 4$, total immunoglobulin $\mathrm{E}$.

The major health hazards of acid anhydrides are mucosal and skin irritation and sensitization of the respiratory tract (1). Welinder et al (2) and Nielsen et al (3) have also reported that methyltetrahydrophthalic anhydride (MTHPA) has irritating effects on the mucous membranes and has sensitizing properties, causing symptoms of the eyes and airways.

We were asked to investigate ocular and nasal problems among workers at a plant where condensers are manufactured with the use of epoxy resin with MTHPA as a hardening agent. Even if allergic rhinitis and conjunctivitis are not considered to be as serious as asthma, it can be troublesome for many workers. Moreover, al- lergic rhinitis may precede occupationally incurred asthma (4). Thus it is important to clarify whether allergic mechanisms are involved in work-related ocular and nasal symptoms.

A person's risk of sensitization depends upon the degree of exposure to potential allergens. Studies of occupational allergy demonstrate that the greater the exposure, the higher the prevalence of sensitization (5). Similar relationships have been documented in association with coffee beans (6), ispaghula (6), and tetrachlorophthalic anhydride (TCPA) (7). Most workers sensitized to these haptens have been smokers. These findings should focus our interest on the relation between some

1 Matsushita Science Center of Industrial Hygiene, Kadoma, Osaka, Japan.

2 Department of Hygiene and Preventive Medicine, Osaka University School of Medicine, Suita, Osaka, Japan.

Reprint requests to: Professor Kanehisa Morimoto, Department of Hygiene and Preventive Medicine, Osaka University School of Medicine, 2-2 Yamada-oka, Suita, Osaka 565, Japan. 
risk factors, for example, atopic history, smoking, and total immunoglobulin (Ig) $\mathrm{E}$ level and the elevation of specific IgE levels.

The purpose of this study was therefore to clarify whether allergic mechanisms are involved in work-related symptoms and to determine whether some risk factors play a significant role in the modulation of MTHPAspecific IgE.

\section{Subjects and methods}

\section{Production and exposure}

The plant that was investigated manufactures condensers for electric appliances. MTHPA is used as a hardening agent in an epoxy resin system for electric insulation and protection. After the condensers are assembled automatically (zones 1 and 2), a small amount of epoxy resin mixture is poured into them (zone 3 ). They pass a curing oven at a temperature of $100^{\circ} \mathrm{C}$. The main exposure originates from the curing ovens. After curing, the condensers are tested electrically (zone 4). Three assembly lines started continuous production in 1982, and 3 new lines were introduced in 1992 . There have been continuous efforts to reduce the exposure to vapors from the curing ovens, especially since 1990. The levels of MTHPA in the air have been measured every 6 months since May 1993. We performed our investigation in December 1994 and February 1995.

\section{Subjects}

Altogether 75 persons worked with MTHPA and 73 (97\%) agreed to participate in the survey. They were divided into 2 types of MTHPA exposure categories, namely, continuous (group $\mathrm{C} ; \mathrm{N}=45$ ) and intermittent (group I; $\mathrm{N}=28$ ). Only 2 in group $\mathrm{C}$ refused for personal reasons.

The workers in group $\mathrm{C}$ had been continuously exposed to MTHPA in the various work zones. Group I consisted of maintenance personnel, assistants, and laboratory personnel. They generally worked in offices or in other parts of the plant where there was no exposure to MTHPA, but they had intermittent, short-time exposure (15-60 min) once a day, a few times a week, or once a month. These workers did not usually use personal protective devices.

Twenty-two former workers (group F) who had worked with MTHPA also took part in the survey. They were randomly selected from 38 former workers by the plant management. The subjects had been away from exposure for a mean of 3.5 (range $0.25-10$ ) years.

Thus altogether 95 workers were studied, of which $37(38.9 \%)$ were women. As referents, 25 persons (including 3 women) from other parts of the workshop and offices with little or no exposure to MTHPA were randomly selected. Informed consent was obtained from all the participants.

\section{Medical examination}

The subjects completed a questionnaire about their symptoms (from the eyes, nose, pharynx, and lower respiratory tract), latency period (time from the start of MTHPA exposure to the first appearance of symptoms), smoking habits, and occupational history. A subject was defined as atopic when he or she had a history of pollenosis, rhinitis, asthma, atopic eczema, or urticaria during childhood or adolescence. Ocular and nasal symptoms were defined as attacks of lacrimation, pruritus and congestion of eyes, sneezing, secretion, and blockage that started after subject joined the plant, with recovery over weekends, holidays or on vacation. Similarly, occupational asthma was defined as attacks of wheezing, dyspnea, and coughing. The subjects were classified as smokers, exsmokers, or nonsmokers. A physician (KY) interviewed the subjects and took a brief history directed towards the symptoms and their relation to work, without knowledge of the symptoms, smoking habits, and occupational histories already recorded on the questionnaires. Venous blood samples were analyzed for the serologic data.

\section{Antibody determinations}

Antigens. A hapten conjugate was prepared from MTHPA and human serum albumin (HSA; Sigma Chemical Co, St Louis, MO, USA), $120 \mathrm{mg}$ of MTHPA being added to a solution of $120 \mathrm{mg}$ of HSA in $40 \mathrm{ml}$ of $0.1 \mathrm{M}$ sodium bicarbonate $(2,8)$. The reaction mixture was stirred at the ambient temperature $\left(25^{\circ} \mathrm{C}\right)$ for $4 \mathrm{~h}$. The protein was purified from MTHPA by ultrafiltration (Millipore $\mathrm{Co}$, Bedford, MA, USA) and diluted with $50 \mathrm{mM}$ phosphate buffer ( $\mathrm{pH} 7.2$ ). The molar ratio of HSA to MTHPA in the conjugate was 1:18-22, analyzed by the method of Bernstein et al (9).

Specific immunoglobulin $E$ antibodies and total immunoglobulin E. Specific IgE antibody to the MTHPA-HSA conjugate was measured by means of the Pharmacia CAP system (10) (Pharmacia Diagnostics AB, Uppsala, Sweden). The results were expressed as units per millimeter, and the detection limit was $0.35 \mathrm{U} / \mathrm{ml}$. Total $\mathrm{IgE}$ levels were also measured by means of the CAP system according to the manufacturer's instructions.

Specific immunoglobulin G4 antibodies. Specific IgG4 antibody to the MTHPA-HSA conjugate was analyzed by enzyme immunoassay (EIA) (Vector Laboratories Inc, Burlingame, CA, USA). Wells of microplates (ICN Biomedicals Inc, Costa Mesa, CA, USA) were coated with $100 \mu \mathrm{l}$ of a conjugate solution $(100 \mu \mathrm{g} / \mathrm{ml} ; 5 \mathrm{mM}$ phosphate buffer, $\mathrm{pH}$ 7.2). The wells were washed 6 times 
with a washing solution ( $5 \mathrm{mM}$ phosphate buffer, $\mathrm{pH} 7.2$, $0.05 \%$ Tween-20) after storage in a refrigerator overnight and then incubated for $2 \mathrm{~h}$ at the ambient temperature $\left(25^{\circ} \mathrm{C}\right)$ with $200 \mu$ l of blocking solution (Block Ace; Snow Brand Milk Products Co Ltd, Tokyo, Japan).

The analytical procedure $(2,8)$ included the following steps, with slight modifications: (i) washing 6 times, (ii) addition of $100 \mu \mathrm{l}$ of a 1:50 dilution (Block Ace) of serum, (iii) incubation for $1 \mathrm{~h}$ at $25^{\circ} \mathrm{C}$, (iv) washing 6 times, (v) addition of $100 \mu \mathrm{l}$ of an optimal dilution (1:1000, Block Ace) of biotinylated anti-IgG4 antibody (Caltag Laboratories Inc, San Francisco, CA, USA), (vi) incubation for $1 \mathrm{~h}$ at $25^{\circ} \mathrm{C}$, (vii) washing 6 times, (viii) addition of $100 \mu \mathrm{l}$ of avidin biotin-ALP $5 \mathrm{mM}$ phosphate buffer, (ix) incubation for $1 \mathrm{~h}$ at $25^{\circ} \mathrm{C}$, (x) washing 10 times, (xi) addition of $100 \mu 1$ of substrate solution (p-nitrophenyl phosphate), (xii) incubation for $15 \mathrm{~min}$ at $25^{\circ} \mathrm{C}$, and (xiii) reading at $405 \mathrm{~nm}$ with an autoreader (Sanko Junyaku Co Ltd, Tokyo, Japan). All the samples were analyzed in triplicate and read against an HSA antigen as a control for binding not specific to MTHPAHSA. The results were expressed as optical density.

Table 1. Air levels of methyltetrahydrophthalic anhydride (MTHPA) in four different zones of the workshop.

\begin{tabular}{lccc}
\hline Zone & $\begin{array}{c}\text { Number of } \\
\text { samples }\end{array}$ & \multicolumn{2}{c}{$\begin{array}{c}\text { MTHPA } \\
\left(\mu \mathrm{g} / \mathrm{m}^{3}\right)\end{array}$} \\
\cline { 3 - 4 } & \multicolumn{3}{c}{$\begin{array}{c}\text { Geometric } \\
\text { mean }\end{array}$} \\
\hline f (assembly) & 5 & 30.2 & $7.47-102$ \\
2 (assembly) & 4 & 63.9 & $14.3-421$ \\
3 (loading and hardening) & 4 & 65.9 & $15.6-278$ \\
4 (inspection) & 4 & 25.5 & $12.9-67.9$ \\
\hline
\end{tabular}

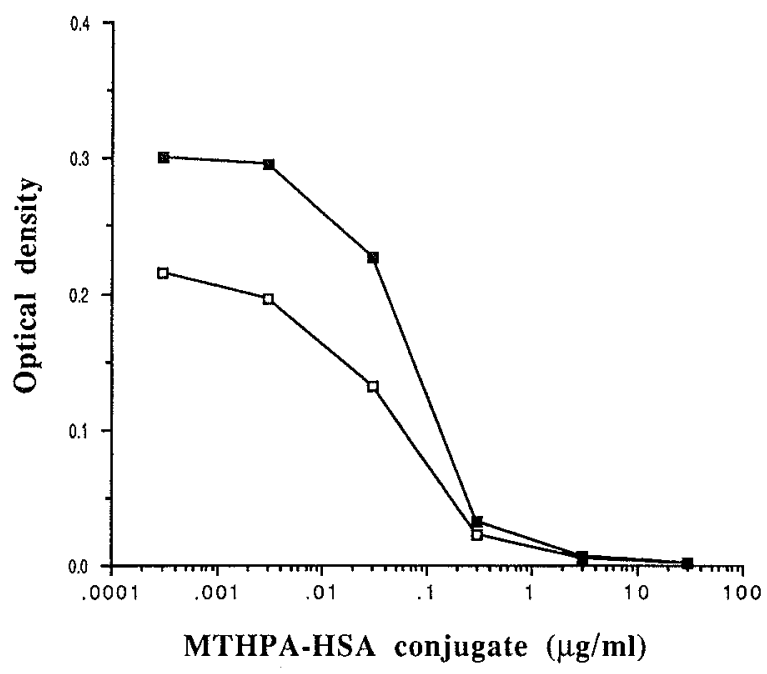

Figure 1. Inhibition curves obtained with MTHPA-HSA conjugate on sera from 2 MTHPA-specific IgG4-positive subjects. (MTHPA = methyltetrahydrophtalic anhydride, HSA = human serum albumin, $1 \mathrm{~g}=$ immunoglobulin)
Specific immunoglobulin G4 inhibition. The MTHPAHSA conjugate was sequentially diluted 10-fold in EIA buffer ( $5 \mathrm{mM}$ phosphate buffer, $\mathrm{pH} 7.2$ ). Each dilution of the conjugate was incubated overnight at $5^{\circ} \mathrm{C}$ with diluted serum with a high level of MTHPA-specific IgG4. MTHPA-specific IgG4 was then measured in these samples by EIA as has already been described.

Air sampling and analysis. MTHPA levels in air in the various work zones were determined by area sampling on silica gel tubes. The sampling rate was $11 / \mathrm{min}$ and the sampling volume was 601 . The anhydride analysis followed, with slight modifications, the procedure described previously (11). The detection limit was $1.0 \mu \mathrm{g} / \mathrm{m}^{3}$ in a 20-1 air sample.

\section{Statistical methods}

The total and specific IgE levels were evaluated in terms of their $\log$ values. Differences were tested by unpaired Student's $t$ test, the Mann-Whitney U-test, the $\chi^{2}$ test, and Fisher's exact test. Pearson's correlation test was used for testing the association between pairs of continuous variables. Multiple logistic regression analysis was used to test the association between specific $\operatorname{IgE}$ production and several variables. These analyses were conducted with the use of the SPSS computer program (12). A P-value of 0.05 or less was considered significant.

\section{Results}

\section{MTHPA levels in air}

The results for the air samples obtained in the various work zones are presented in table 1. The MTHPA levels varied from 7.47 to $421 \mu \mathrm{g} / \mathrm{m}^{3}$. The curing ovens leaked up to $7 \mathrm{mg}$ MTHPA $/ \mathrm{m}^{3}$.

The American Conference of Governmental Industrial Hygienists has recommended $6.1 \mathrm{mg} / \mathrm{m}^{3}$ as a limit for phthalic anhydride (PA) exposure during an 8-h workshift, but it has not suggested a limit for MTHPA exposure (13). The geometric mean concentrations of MTHPA ranged from 25.5 to $65.9 \mu \mathrm{g} / \mathrm{m}^{3}$ and were considerably lower than the PA control limit.

\section{Inhibition of the immunoassay reactions}

As shown in figure 1, the immunoassay (EIA) reactions in the measurement of MTHPA-specific IgG4 were inhibited in a dose-dependent manner by the MTHPAHSA conjugate but not by HSA. The successful inhibition of the EIA reactions by the conjugate indicates that the EIA was specific for the MTHPA-HSA conjugate.

\section{Demographic data}

Table 2 shows the characteristics of the population by type of MTHPA exposure. The gender distribution was 
Table 2. Profiles of workers in the various methyltetrahydrophthalic anhydride (MTHPA) exposure groups. ( $\mathrm{g}=$ immunoglobulin)

\begin{tabular}{|c|c|c|c|c|c|c|c|c|c|c|c|c|c|c|c|c|c|c|c|}
\hline \multirow[b]{3}{*}{$\begin{array}{l}\text { Continuous } \\
\text { (group C) } \\
N=45\end{array}$} & \multirow{2}{*}{\multicolumn{2}{|c|}{$\begin{array}{l}\text { Gender } \\
\begin{array}{c}\text { Male Fe- } \\
\text { (N) male } \\
\text { (N) }\end{array}\end{array}$}} & \multirow{2}{*}{\multicolumn{2}{|c|}{$\frac{\text { Age (years) }}{\text { Mean Range }}$}} & \multirow{2}{*}{$\begin{array}{c}\begin{array}{c}\text { Exposure time } \\
\text { (years) }\end{array} \\
\text { Mean Range }\end{array}$} & \multicolumn{2}{|c|}{$\begin{array}{l}\text { Current } \\
\text { smokers }\end{array}$} & \multicolumn{2}{|c|}{$\begin{array}{l}\text { Atopic } \\
\text { history }\end{array}$} & \multicolumn{2}{|c|}{$\begin{array}{c}\text { Total lgE level } \\
(\mathrm{IU} / \mathrm{ml})\end{array}$} & \multicolumn{2}{|c|}{$\begin{array}{c}\text { Positive } \\
\text { specific } \\
\text { lgE }\end{array}$} & \multicolumn{2}{|c|}{$\begin{array}{l}\text { Specific } \lg E \\
\text { level }(\mathrm{U} / \mathrm{m} \mid)^{1}\end{array}$} & \multicolumn{2}{|c|}{$\begin{array}{l}\text { Positive } \\
\text { specific } \\
\text { lgG4c }\end{array}$} & \multicolumn{2}{|c|}{$\begin{array}{c}\text { Specific } \\
\text { IgG4 level }(O D)\end{array}$} \\
\hline & & & & & & $N$ & $\%$ & $\mathrm{~N}$ & $\%$ & $\begin{array}{l}\text { Geo- } \\
\text { metric } \\
\text { mean }\end{array}$ & Range & N & $\%$ & $\begin{array}{l}\text { Geo- } \\
\text { metric } \\
\text { mean }\end{array}$ & Range & N & $\%$ & Mean & Range \\
\hline & 17 & $28^{d}$ & 34.5 & $19-53$ & $5.2^{e} \quad 0.2-13$ & $5^{\dagger}$ & 11.1 & 6 & 13.3 & 59.6 & $5.13-1290$ & 26 & 57.7 & 8.1 & $0.58-106$ & $24^{\circ}$ & 53.3 & $0.102^{\mathrm{k}}$ & $0-0.333$ \\
\hline $\begin{array}{l}\text { Intermittent } \\
\text { (group l) } \\
\mathrm{N}=28\end{array}$ & 23 & 5 & 35.0 & $19-58$ & $7.4 \quad 0.5-19$ & 11 & 39.3 & 7 & 25.0 & 102 & $6.15-895$ & 20 & 71.4 & 7.6 & $0.50-105$ & 5 & 17.9 & 0.026 & $0-0.183$ \\
\hline $\begin{array}{l}\text { Former } \\
\text { (group F) } \\
N=22\end{array}$ & 18 & 4 & 37.5 & $19-47$ & $5.8 \quad 0.1-18$ & 8 & 36.4 & 5 & 22.7 & 82.3 & $13.4-637$ & 15 & 68.2 & 3.7 & $0.74-15.7$ & 5 & 22.7 & 0.021 & $0-0.122$ \\
\hline $\begin{array}{l}\text { Referents } \\
N=25\end{array}$ & 22 & 3 & 37.0 & $21-54$ & . & 14 & 56.0 & 2 & 8.0 & 94.8 & $1.66-1466$ & .. & .. & .. & .. & .. & .. & .. & .. \\
\hline $\begin{array}{l}\text { a Values of } \\
\text { b Measured } \\
\text { - Values of } \\
\text { - Significan } \\
\text { - Significan } \\
\text { 1 Significan } \\
\text { - Significan } \\
\text { : Significan }\end{array}$ & $\begin{array}{l}\text { in sub } \\
0.020 \\
\text { versu } \\
\text { versu } \\
\text { versu } \\
\text { versu } \\
\text { versus }\end{array}$ & $\begin{array}{l}\text { jects } \\
0 \text { cons } \\
\text { s grou } \\
\text { s grou } \\
\text { s grou } \\
\text { s grou } \\
\text { s grou }\end{array}$ & $\begin{array}{l}\text { conside } \\
\text { with po } \\
\text { sidered } \\
\text { ups I, F } \\
\text { up I (P } \\
\text { ups I, F } \\
\text { ups I an } \\
\text { ups I an }\end{array}$ & $\begin{array}{l}\text { ered posit } \\
\text { sitive spe } \\
\text { positive } \\
\text {, and refe } \\
<0.05) \text {. } \\
\text {, and refe } \\
\text { id } F \text { ( } P<0 \\
\text { id } F(P<0\end{array}$ & $\begin{array}{l}\text { ive. } \\
\text { ific IgE. } \\
\text { in the basis of } 2 \\
\text { ents }(P<0.001) \\
\text { ents }(P<0.02) \text {. } \\
.02) \text {. } \\
.002) \text {. }\end{array}$ & me & +35 & & the re & ferents. & & & & & & & & & \\
\hline
\end{tabular}

significantly different in group $\mathrm{C}(\mathrm{P}<0.001)$ because more than half of the workers in the manufacturing process were women. The workers intermittently exposed (group I) had been exposed, on the average, for a longer period than those in group $\mathrm{C}(\mathrm{P}<0.05)$. Group $\mathrm{C}$ included a smaller proportion of smokers than did the other groups $(\mathrm{P}<0.02)$.

\section{Immunologic data}

There were no significant differences between the groups with regard to the total IgE level (table 2). No significant differences were found in the frequency or the level of positive specific IgE antibody among the 3 groups. How- ever, the frequency of positive specific IgG4 in group C was significantly higher $(\mathrm{P}<0.02)$ than that in groups I and $\mathrm{F}$. The mean specific IgG4 level of IgE-sensitized subjects in group $\mathrm{C}$ was also significantly higher $(\mathrm{P}<0.002)$ than that of IgE-sensitized subjects in groups $\mathrm{I}$ and $\mathrm{F}$. As shown in table 3, moreover, the association between specific IgE and IgG4 antibodies was significant $(\mathrm{P}<0.0005)$ for the subjects in group $\mathrm{C}$, but not for those in groups I and $\mathrm{F}$.

All the specific IgE and IgG4 values for the 25 referents were $<0.35 \mathrm{U} / \mathrm{ml}$ and $<0.020$, respectively.

Figure 2 shows a scattergram of the 95 pairs of specific and total IgE levels on a log scale. The correlation

Table 3. Work-reiated symptoms of workers sensitized to immunoglobulin $(\mathrm{Ig}) E$ (positive specific $\mathrm{lg} E$ in serum) and unsensitized workers with current exposure to methyltetrahydrophthalic anhydride (MTHPA). (NS = not significant)

\begin{tabular}{|c|c|c|c|c|c|c|c|c|c|c|}
\hline \multirow[t]{3}{*}{ Symptom } & \multicolumn{5}{|c|}{ Continuous (group C) } & \multicolumn{5}{|c|}{ Intermittent (group I) } \\
\hline & \multicolumn{2}{|c|}{$\begin{array}{c}\text { Sensitized } \\
\text { workers } \\
(N=26)\end{array}$} & \multicolumn{2}{|c|}{$\begin{array}{c}\text { Unsensitized } \\
\text { workers } \\
(\mathrm{N}=19)\end{array}$} & \multirow[t]{2}{*}{$\mathrm{P}$-value } & \multicolumn{2}{|c|}{$\begin{array}{l}\text { Sensitized } \\
\text { workers } \\
(N=20)\end{array}$} & \multicolumn{2}{|c|}{$\begin{array}{c}\text { Unsensitized } \\
\text { workers } \\
(N=8)\end{array}$} & \multirow[t]{2}{*}{$P$-value } \\
\hline & $N$ & $\%$ & $\mathbb{N}$ & $\%$ & & $\therefore N$ & $\%$ & $N$ & $\%$ & \\
\hline Positive specific IgG4a & 20 & 76.9 & 4 & 21.1 & $<0.0005^{b}$ & 5 & 25.0 & - & & NS \\
\hline \multicolumn{11}{|l|}{ Work-related symptoms } \\
\hline $\begin{array}{l}\text { Eyes } \\
\text { Nose }\end{array}$ & $\begin{array}{l}17 \\
23\end{array}$ & $\begin{array}{l}65.4 \\
88.5\end{array}$ & $\begin{array}{l}5 \\
5\end{array}$ & $\begin{array}{l}26.3 \\
26.3\end{array}$ & $\begin{array}{l}<0.02^{b} \\
<0.0001^{b}\end{array}$ & $\begin{array}{l}11 \\
17\end{array}$ & $\begin{array}{l}55.0 \\
85.0\end{array}$ & 1 & $\begin{array}{c}12.5 \\
\cdot\end{array}$ & $\begin{array}{c}\mathrm{NS} \\
<0.0001^{\circ}\end{array}$ \\
\hline $\begin{array}{l}\text { Sneezing } \\
\text { Secretion } \\
\text { Blockage }\end{array}$ & $\begin{array}{l}20 \\
22 \\
15\end{array}$ & $\begin{array}{l}76.9 \\
84.6 \\
57.7\end{array}$ & $\begin{array}{l}4 \\
3 \\
3\end{array}$ & $\begin{array}{l}21.1 \\
15.8 \\
15.8\end{array}$ & $\begin{array}{l}<0.0005^{\mathrm{b}} \\
<0.0001^{\circ} \\
<0.01^{\mathrm{b}}\end{array}$ & $\begin{array}{r}16 \\
17 \\
5\end{array}$ & $\begin{array}{l}80.0 \\
85.0 \\
25.0\end{array}$ & - & . & $\begin{array}{c}<0.0005^{\circ} \\
<0.0001^{\circ} \\
\text { NS }\end{array}$ \\
\hline Pharynx & 4 & 15.4 & 2 & 10.5 & NS & - & , & - & . & NS \\
\hline Cough & 5 & 19.2 & 1 & 5.3 & NS & 3 & 15.0 & - & . & NS \\
\hline Asthma & - & . & - & . & NS & - & . & - & . & NS \\
\hline
\end{tabular}

a Values of $>0.020$ (OD) were considered positive.

- Significant versus sensitized in group C.

- Significant versus sensitized in group I. 


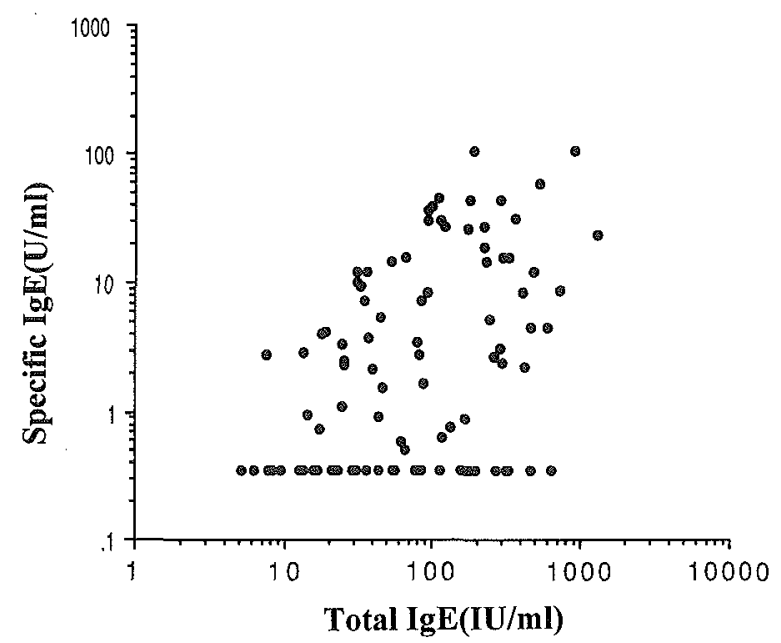

Figure 2. Scattergram of the MTHPA-specific and total lgE levels of 95 workers with occupational exposure to MTHPA. Specific IgE values of $<0.35 \mathrm{U} / \mathrm{ml}$ were plotted and calculated as $0.35 \mathrm{U} / \mathrm{ml}$. (MTHPA = methyltetrahydrophtalic anhydride, $\mathrm{lg}=$ immunoglobulin)

between the $\log$ values of the specific and total $\operatorname{IgE}$ was highly significant $(r=0.43, P<0.0001)$.

\section{Associations between specific antibodies and work- related symptoms}

IgE-sensitized workers with current exposure to MTHPA generally complained of more symptoms of the eyes and nose than did unsensitized workers (table $3 ; \mathrm{P}<0.02$ ), whereas there was no association between work-related symptoms and specific IgG4 antibodies. The IgE-sensitized workers in group $\mathrm{C}$ had higher frequencies of nasal blockage than did those in group I $(\mathrm{P}<0.05)$. The latency period ranged from "immediately" to 10 years. None of the subjects had yet had symptoms of work-related asthma.

\section{Risk factors for sensitization to MTHPA}

Table 4 shows the characteristics of the workers classified by the presence or absence of specific IgE antibodies. The subjects were originally classified as smokers, ex-smokers, or nonsmokers. Because the group of ex-smokers was small $(\mathrm{N}=5)$, the ex-smokers were com- bined with smokers for a comparison with nonsmokers. Neither gender nor atopic history contributed to the production of specific IgE, whereas age $(\mathrm{P}<0.02)$, exposure time $(\mathrm{P}<0.05)$, smoking habits $(\mathrm{P}<0.05)$, and total IgE level $(\mathrm{P}<0.005)$ all contributed to the production of specific IgE.

Further confirmation of the contributions of smoking and the total IgE level came from the multiple logistic regression analysis. Several risk factors (gender, age, exposure time, atopic history, smoking habits, and total $\mathrm{IgE}$ level) were dichotomized and scored as 0 (low risk) or 1 (high risk).

As shown in table 5, the resulting relative risk (RR) ranged from 2.0 to 4.7 . Two factors, smoking and total IgE level, were found to contribute significantly ( $\mathrm{P}<0.05$ and $\mathrm{P}<0.005$ and $\mathrm{RR} 4.1$ and 4.7 , respectively) to the elevation of the specific IgE level. These results were similar to those obtained by using univariate analyses. Gender, age, exposure time, and atopic history did not play a significant role in producing specific $\operatorname{IgE}$.

\section{Discussion}

In the plant studied, which produced condensers for electric appliances, the frequency of positive specific $\operatorname{IgE}$ in workers currently exposed to MTHPA was 46 of 73 (63\%), much higher than that $(7-44 \%)$ found in previous studies of workers exposed to MTHPA $(2,15)$, hexahydrophthalic anhydride (HHPA) (16, 17), PA (8), TCPA $(7,18)$, or trimellitic anhydride (19). Of the 75 current workers with exposure, $73(97 \%)$ participated in this survey. It is unlikely that the high frequency was due to selection bias. Differences in the frequency of positive specific IgE could be partly attributed to higher peak or average exposures. This result demonstrates that MTHPA, like the other acid anhydrides, has a high sensitizing ability.

The frequency of positive specific IgE in this study was much higher than that for the continuously MTHPAexposed workers in our previous study (15) $(58 \%$ and $24 \%$ ) because the exposure intensity was much lower in

Table 4. Profiles of workers by presence or absence of specific immunoglobulin (Ig) $E$ antibody. (NS = not significant)

\begin{tabular}{|c|c|c|c|c|c|c|c|c|c|c|c|}
\hline & \multirow{2}{*}{\multicolumn{2}{|c|}{ Gender }} & \multirow{2}{*}{\multicolumn{2}{|c|}{ Age (years) }} & \multirow{2}{*}{\multicolumn{2}{|c|}{$\begin{array}{c}\text { Exposure } \\
\text { time (years) }\end{array}$}} & \multirow[t]{3}{*}{$\begin{array}{c}\text { Atopic } \\
\text { history (N) }\end{array}$} & \multicolumn{2}{|c|}{ Smoking } & \multirow{2}{*}{\multicolumn{2}{|c|}{$\begin{array}{l}\text { Total lgE level } \\
(\mid \mathrm{U} / \mathrm{ml})\end{array}$}} \\
\hline & & & & & & & & Smokers & Ex- & & \\
\hline & $\begin{array}{l}\text { Male } \\
\text { (N) }\end{array}$ & $\begin{array}{l}\text { Female } \\
(N)\end{array}$ & Mean & Range & Mean & Range & & (N) & $\begin{array}{l}\text { smokers } \\
(\mathbb{N})\end{array}$ & $\begin{array}{c}\text { Geometric } \\
\text { mean }\end{array}$ & Range \\
\hline Specific $\lg E(t)^{\mathrm{a}}$ & 39 & 22 & 37.2 & $19-58$ & 6.7 & $0.2-15$ & 10 & 18 & 5 & 101 & $7.48-1291$ \\
\hline $\begin{array}{l}\text { Specific } \lg E(-) \\
(N=34)\end{array}$ & 19 & 15 & 31.9 & $19-47$ & 4.8 & $0.1-19$ & 8 & 6 & 0 & 44.8 & $5.13-637$ \\
\hline P-value ${ }^{b}$ & \multicolumn{2}{|c|}{ NS } & \multicolumn{2}{|c|}{$<0.02$} & \multicolumn{2}{|c|}{$<0.05$} & NS & \multicolumn{2}{|c|}{$<0.05$} & \multicolumn{2}{|c|}{$<0.005$} \\
\hline
\end{tabular}

a Values of $>0.35 \mathrm{U} / \mathrm{ml}$ were considered positive.

- Specific $\lg E(+)$ versus specific $\lg E(-)$. 
the latter group $\left(1.09-22.4 \mu \mathrm{g} / \mathrm{m}^{3}\right)$. This result indicates that it is important to control the effects of MTHPA by reducing exposure levels.

The subjects in our study were investigated between 1994 and 1995. The airborne MTHPA concentrations were fairly low (geometric mean 25.5 to $65.9 \mu \mathrm{g} / \mathrm{m}^{3}$ ) at the time of the investigation. Among the currently exposed workers, the frequency of positive specific IgE in workers with $\geq 5$ years of exposure time was significantly $(\mathrm{P}<0.05)$ higher than that in workers with $<5$ years of exposure time ( $75 \%$ and $51 \%$, respectively). Then, because of the high frequency of positive specific IgE, it is possible that the airborne MTHPA concentrations were higher before 1994 and that the high frequency we found mainly reflects previous exposure.

Groups $\mathrm{C}$ and I did not differ in the frequency or level of positive specific IgE. This finding suggests that intermittent short-time exposures may affect the production of specific $\operatorname{IgE}$ antibodies. This finding is consistent with the results of a study in a factory using HHPA (17), where 5 of 7 workers positive for specific $\operatorname{IgE}$ in the group with the lowest exposures reported frequent shorttime (minutes per day) exposures exceeding $50 \mu \mathrm{g} / \mathrm{m}^{3}$. Our interest should therefore be focused on exposure levels of workers intermittently exposed to MTHPA. However, intermittent exposures have not yet been measured. It is notable that the specific IgE level of the $\operatorname{IgE}$ sensitized subjects in group $\mathrm{F}$ was not significantly different from that of IgE-sensitized subjects in groups C and I, even though the time away from exposure ranged from 0.25 to 10 (mean 3.5 ) years.

In contrast, the frequency of positive specific IgG4 in group $\mathrm{C}$ differed significantly $(\mathrm{P}<0.02)$ from that of groups I and F. This result suggests that the intensity of MTHPA exposure was the major determinant of specific IgG4 levels, and it was in accordance with that of a previous study of MTHPA-exposed workers (2).

As shown in table 3, work-related ocular and nasal symptoms were significantly associated with MTHPAspecific IgE. This finding indicates that there is an IgEmediated mechanism in most cases of work-related symptoms associated with MTHPA exposure. Our results differed considerably from those of another study (3), in which no significant differences were found for ocular and nasal symptoms between IgE-sensitized and unsensitized subjects. This finding can be partially explained by the fact that our subjects were not exposed to chemicals other than MTHPA, such as the thermal degradation products of plastics (3), which may have irritating effects on mucous membranes.

No association was found between work-related symptoms and specific IgG4 antibodies. Specific IgG4 antibodies are not protective, as IgE-sensitized subjects displayed the work-related symptoms regardless of the presence of specific IgG4.
Table 5. Relative risk (RR) of various factors for elevated MTHPAspecific IgE (multiple logistic regression analysis). ${ }^{\text {a }}$ (MTHPA $=$ methyltetrahydrophthalic anhydride, $95 \% \mathrm{Cl}=95 \%$ confidence interval, $N S=$ not significant, lgE = immunoglobulin $E$ )

\begin{tabular}{|c|c|c|c|c|}
\hline Factor & High risk & $\mathrm{RR}^{\mathrm{b}}$ & $95 \% \mathrm{Cl}$ & P-value \\
\hline Gender & Male & 2.0 & $0.6-6.0$ & NS \\
\hline Age (years) & $\geq 35$ & 2.1 & $0.8-5.8$ & NS \\
\hline Exposure time (years) & $\geq 5$ & 2.5 & $0.9-6.6$ & NS \\
\hline Atopic history & Present & 2.0 & $0.6-6.7$ & NS \\
\hline Smoking habits & $\begin{array}{c}\text { Current and } \\
\text { ex- }\end{array}$ & 4.1 & $1.1-15.3$ & $<0.05$ \\
\hline Total IgE level (IU/ml) & $\geq 80$ & 4.7 & $1.7-13.5$ & $<0.005$ \\
\hline
\end{tabular}

a The cut-off point of the elevated specific IgE level for high-risk status ( $\geq 80 \mathrm{lU} / \mathrm{ml}$ ) was based on the distribution of the total laE level in MTHPA-specific lgE negative and positive populations. Our estimate of $80 \mathrm{IU} / \mathrm{ml}$ is in agreement with the estimates of 2 other reports, $95 \mathrm{IU} / \mathrm{ml}$ (22) and $100 \mathrm{LU} / \mathrm{ml}(14)$

- Odds ratio between low risk and high risk.

Exposure to acid anhydrides can cause occupational allergic diseases, including asthma. In previous studies, asthma was found in $2 \%$ of the workers exposed to TCPA (20), $14 \%$ of the workers exposed to PA (8), $11 \%$ of the workers exposed to HHPA (16), and $10 \%$ of the workers exposed to MTHPA (3). In the present study, however, no subject had yet developed symptoms of work-related asthma. It is not known whether the low exposure levels at the time of the survey can explain this phenomenon. Additional prospective studies among IgEsensitized subjects need to be done to address this question.

There are conflicting reports on the effect of the duration of exposure on the production of specific $\operatorname{IgE}$ antibodies in workers exposed to acid anhydride (7, 18, 21). Zeiss et al (21) stated that the presence or absence of an antibody response was not simply the result of exposure time but was related to as yet unidentified host characteristics. In this study, exposure time was not associated with sensitivity to MTHPA (table 5).

As shown in tables 4 and 5, smoking contributed to the elevation of specific IgE levels $(\mathrm{P}<0.05)$. This result is similar to those of occupational population studies (6, 7). However, a positive relationship between smoking and specific IgE has not been demonstrated for exposure to PA (8), HHPA (17), or MTHPA (2). Further studies are required to clarify the association of smoking with the production of MTHPA-specific IgE in a larger sample size.

As shown in table 4, the total IgE level was significantly higher in the IgE-sensitized workers than in the unsensitized workers $(\mathrm{P}<0.005)$. Furthermore, there was a positive correlation between MTHPA-specific and total IgE levels ( $\mathrm{r}=0.43, \mathrm{P}<0.0001)$ (figure 2 ). By multiple logistic regression analysis (table 5 ), it was further confirmed that the high total $\mathrm{IgE}$ levels $(\geq 80 \mathrm{IU} / \mathrm{ml}$ ) made an independent contribution to the production of 
MTHPA-specific $\operatorname{IgE}(\mathrm{P}<0.005)$. This result is in agreement with those of several other studies $(22-25)$ and suggests that the total IgE level in an individual may represent his or her potential for immunoallergic responses. However, it is possible that subjects who became sensitized would have an increased level of total IgE. Further prospective studies to check the total $\operatorname{IgE}$ levels before assignment to the assembly lines are therefore needed to confirm the causal relation of high total $\operatorname{IgE}$ levels with sensitization to MTHPA.

As stated, MTHPA is a potent sensitizer that induces specific IgE production and causes ocular and nasal symptoms even at very low exposure levels, and therefore it is difficult to control the effects of MTHPA simply by controlling exposure in the work environment. We believe that workers with a total IgE level of less than $80 \mathrm{IU} / \mathrm{ml}$, along with improvements in the work environment, should be given priority in the assignment of the manufacturing process to prevent allergic disorders caused by MTHPA.

\section{Acknowledgments}

This work was supported in part by a grant-in-aid for scientific research from the Ministry of Education, Science, Sports and Culture of Japan. We thank Ms Y Noguchi and Mr Y Kunitani (Matsushita Science Center Of Industrial Hygiene) for their encouragement of our study.

\section{References}

1. Venabies KM. Low molecular weight chemicals, hypersensitivity, and direct toxicity: the acid anhydrides. $\mathrm{Br} J$ Ind Med 1989:46:222 -32 .

2. Welinder H, Nielsen J, Gustavsson C, Bensryd I, Skerfving S. Specific antibodies to methyltetrahydrophthalic anhydride in exposed workers. Clin Exp Allergy 1990;20:639— 45.

3. Nielsen J, Welinder $\mathrm{H}$, Horstmann V, Skerfving S. Allergy to methyltetrahydrophthalic anhydride in epoxy resin workers. Br J Ind Med 1992;49:769-75.

4. Wernfors M, Nielsen J, Schütz A, Skerfving S. Phthalic anhydride-induced occupational asthma. Int Arch Allergy Appl Immunol 1986;79:77-82.

5. Shirakawa T, Morimoto K. Lifestyle effect on total IgE. Allergy 1991;46:561-9.

6. Zetterström O, Osterman K, Machado O, Johansson SGO. Another smoking hazard: raised serum IgE concentration and increased risk of occupational allergy. BMJ 1981;283:12157.

7. Venables KM, Topping MD, Howe W, Luczynska CM, Hawkins R, Taylor AJ. Interaction of smoking and atopy in producing specific IgE antibody against a hapten protein conjugate. BMJ 1985;290:201-4.

8. Nielsen J, Welinder H, Schütz A, Skerfving S. Specific serum antibodies against phthalic anhydride in occupationally exposed subjects. J Allergy Clin Immunol 1988;82:126-33.
9. Bernstein DI, Gallagher JS, D'Sousa L, Bernstein IL. Heterogeneity of specific-IgE responses in workers sensitized to acid anhydride compounds. J Allergy Clin Immunol 1984;74:794 801 .

10. Bousquet J, Chanez P, Chanel I, Michel F-B. Comparison between RAST and Pharmacia CAP system: a new automated specific IgE assay. J Allergy Clin Immunol 1990;85:1039 43.

11. Pfäffli P, Savolainen H, Keskinen H. Determination of carboxylic acids in biological samples as their trichloroethylesters by gas chromatography. Chromatographia 1989;27: 483-8.

12. SPSS Inc. SPSSX user's guide. Chicago (IL): SPSS Inc, 1986.

13. American Conference of Governmental Industrial Hygienists (ACGIH). Threshold limit values for chemical substances in work air adopted by ACGIH for 1994-95. Cincinnati $(\mathrm{OH})$ : ACGIH, 1995.

14. Burrows B, Martinez FD, Halonen M, Barbee R, Cline MG. Association of asthma with serum IgE levels and skin-test reactivity to allergens. N Engl J Med 1989;320:271-7.

15. Yokota K, Johyama Y, Yamaguchi K, Fujiki Y, Takeshita T, Morimoto K. Study on allergic rhinitis in workers exposed to methyltetrahydrophthalic anhydride. Environ Health Prev Med 1996;1:133-35.

16. Moller DR, Gallagher JS, Bernstein DI, Wilcox TH, Burroughs HE, Bernstein IH. Detection of IgE-mediated respiratory sensitization in workers exposed to hexahydrophthalic anhydride. J Allergy Clin Immunol 1985;75:663-72.

17. Welinder HE, Jönsson BAG, Nielsen JE, Ottosson HE, Gustavsson CA. Exposure-response relationships in the formation of specific antibodies to hexahydrophthalic anhydride in exposed workers. Scand J Work Environ Health 1994;20: $459-65$.

18. Liss GM, Bernstein D, Genesove L, Roos JO, Lim J. Assessment of risk factors for IgE-mediated sensitization to tetrachlorophthalic anhyride. J Allergy Clin Immunol 1993;92: $237-47$

19. Grammer LC, Harris KE, Sonenthal KR, Ley C, Roach DE. A cross-sectional survey of 46 employees exposed to trimellitic anhydride. Allergy Proc 1992;3:139—42.

20. Howe W, Venables KM, Topping MD, Dally MB, Hawkins R, Law JS, et al. Tetrachlorophthalic anhydride asthma: evidence for specific IgE antibody. J Allergy Clin Immunol 1983; 71:5-11.

21. Zeiss CR, Wolkonsky P, Chacon R, Tuntland PA, Levitz D, Prunzansky JJ, et al. Syndromes in workers exposed to trimellitic anhydride: a longitudinal clinical and immunologic study. Ann Intern Med 1983;98:8-12.

22. Marsh DG, Bias WB, Ishizaka K. Genetic control of basal serum immunoglobulin $E$ level and its effect on specific reaginic sensitivity. Proc Natl Acad Sci USA 1974;71: 3588-92.

23. Omenaas E, Bakke P, Elsayed S, Hanoa R, Gulsvik A. Total and specific serum IgE levels in adults: relationship to sex, age and environmental factors. Clin Exp Allergy 1994;24 530-9.

24. Brown WG, Halonen MJ, Kaltenborn WT, Barbee RA. The relationship of respiratory allergy, skin test reactivity, and serum IgE in a community population sample. J Allergy Clin Immunol 1979;63:328-35.

25. Herbert FA, Weimer N, Salkie ML. RAST and skin test screening in the investigation of asthma. Ann Allergy 1982;49: $311-4$.

Received for publication: 22 July 1996 